\title{
Chemical Properties, Rheological Behavior, and Melissopalynological Analysis of Selected Brazilian Honeys from Hovenia dulcis Flowering
}

\author{
Helayne Aparecida Maieves ${ }^{1,2}$ \\ https://orcid.org/0000-0002-3056-1381
}

Luana Carolina Bosmuler Züge ${ }^{3}$

https://orcid.org/0000-0003-4539-8887

Gerson Lopes Teixeira ${ }^{4 *}$

https://orcid.org/0000-0002-3442-3525

\author{
Montaña Cámara ${ }^{1}$ \\ https://orcid.org/0000-0001-9232-0703
}

\author{
Rosemary Hoffmann Ribani ${ }^{3}$ \\ https://orcid.org/0000-0001-8279-7428 \\ María Cortes Sánchez-Mata ${ }^{1}$ \\ https://orcid.org/0000-0002-7292-8663
}

${ }^{1}$ Complutense University of Madrid, Department of Nutrition and Food Science, Madrid, Spain. ${ }^{2}$ Federal University of Pelotas, Department of Nutrition, Pelotas, Rio Grande do Sul, Brazil. ${ }^{3}$ Federal University of Paraná, Graduate Program of Food Engineering, Curitiba, Paraná, Brazil. ${ }^{4}$ Federal University of Santa Catarina, Department of Food Science and Technology, Florianópolis, Santa Catarina, Brazil.

Received: 2019.12.10; Accepted: 2020.03.17.

${ }^{*}$ Correspondence: gerson775@gmail.com; Tel.: +55-48-32715367 (G.L.T.)

\section{HIGHLIGHTS}

- Brazilian honeys from Hovenia dulcis are high-quality products.

- H. dulcis honeys have excellent chemical and physicochemical properties.

- Rheology shows that $H$. dulcis honeys are pseudoplastic fluids.

Abstract: Monofloral honeys are high-added-value food, a reason for constant cases of fraud. This study investigated Brazilian monofloral honeys from Hovenia dulcis flowering produced by Apis mellifera and Tetragonisca angustula bees. Chemical, physicochemical, rheological, and melissopalynological analysis were assessed. Properties such as moisture, $\mathrm{pH}$, ashes, total acidity, total available carbohydrate, and soluble sugars of all analyzed honey samples agreed with the established by the legislation. All the honey samples were satisfactorily fitted by both Ostwald-de Waele and Casson rheological models revealing homogenous products, mostly presenting pseudoplastic character. The melissopalynology confirmed the presence of $H$. dulcis pollen in the MH samples; however, some honeys did not show $>45 \%$ pollen of $H$. dulcis, thus revealing mislabeling cases. Continuous evaluation of honey is necessary, once this is a valuable food frequently involved in frauds, hence causing problems to consumers.

Keywords: Melissopalynology; monofloral honey; Japanese raisin tree; rheological properties; mislabeling. 


\section{GRAPHICAL ABSTRACT}

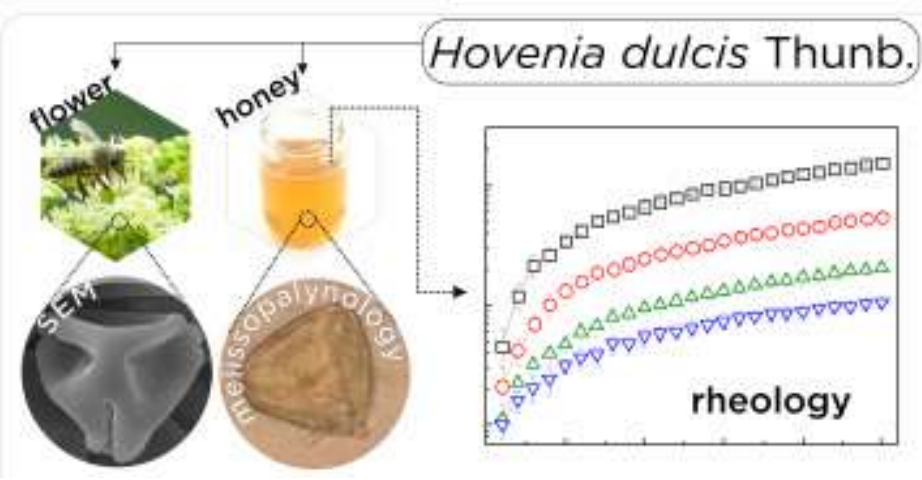

\section{INTRODUCTION}

Honey is a valuable and nutritious food recognized by its aromatic, sweet, and viscous properties, which is mainly composed of reducing sugars such as fructose, glucose, and sucrose, in addition to other minor compounds [1,2]. It can be used as a natural sweetener, and its consumption is associated with health benefits because it is rich in biologically active compounds [3-6]. This complex matrix may suffer interference from various environmental factors, such as weather, flowering, geographical regions where the bee species live [7]. All these factors influence the concentration of sugars, minerals, vitamins, and bioactive compounds. Thus, the aroma, taste, and color of honey differ according to its geographical origin and floral source [2,8,9], which is usually written on the label of this product in the Brazilian market to indicate what is the dominant pollen of its composition.

The studies involving the elucidation of pollen types are crucial to understanding its contribution to the honey's properties. Many plant species play an essential role in this process because they present distinctive morphological pollen characters that have an impact on honey quality [10]. In the case of monofloral honey $(\mathrm{MH})$, the labeling can proceed if there is at least $45 \%$ of a dominant pollen grain from the same plant. In this sense, attention has been given to the mislabeling of $\mathrm{MH}$, while growing the interest in authenticating them through pollen analysis and chemical approaches [11,12].

The characterization of $\mathrm{MH}$ is usually performed by melissopalynology, which allows the authentication of the dominant pollen $[9,13,14]$. However, other improved techniques are reported, as the case of atmospheric pressure chemical ionization mass spectrometry [8], light and scanning electron microscopy [10], liquid chromatography [13], in addition to chemometric tools [12,15] and rheology [7,16]. The rheological properties have been extensively reported as significant characteristics that affect the texture, sensory rating as well as other quality parameters of foods, including shelf stability during storage $[7,17,18]$.

The Hovenia dulcis Thunb. known as "Japanese raisin tree" or "uva-do-japão" and "cajueiro-japonês" in Brazil is a tree widely disseminated throughout Southern and Southeastern Brazil [18], which flowering contributes to the production of honey currently sold in Brazil as Hovenia dulcis honey. These honeys from nonconventional flowering are usually sold for higher prices than the most common types because they are produced in small scales and are available only in specialized markets. This is one of the reasons that may stimulate fraud by mixing $\mathrm{MH}$ from "high-valued flowering" to the low-quality ones and selling them as an authentic product.

Thus, this study was performed to evaluate the chemical, physicochemical and rheological properties, as well as the melissopalynological characteristics of honey samples labeled by the manufacturer as coming from the flowering of $H$. dulcis from different Brazilian states.

\section{MATERIAL AND METHODS}

\section{Honey samples}

Five H. dulcis honey $(\mathrm{HDH})$ samples were evaluated in this study. Four samples from Apis mellifera were obtained in the Brazilian states of Paraná (municipality of Dois Vizinhos), Rio Grande do Sul (Roca Sales), Santa Catarina (Araranguá), and São Paulo (Mairinque). Those samples were coded as PR, RSa, SC, and SP, respectively. The fifth sample was produced by Tetragonisca angustula stingless bee, also obtained from the Rio Grande do Sul (codified as RSb). 


\section{Physicochemical characterization}

The HDH samples were analyzed according to AOAC Official Methods [19] for their moisture (desiccation at $100{ }^{\circ} \mathrm{C}$ ), ashes (incineration), total acidity, and formol index (titration), $\mathrm{pH}$, color (Pfund scale), electrical conductivity, hydroxymethylfurfural (UV spectrophotometry), protein (Kjeldahl method) and water activity (AquaLab Decagon Devices).

\section{Total Available Carbohydrate (TAC)}

The TAC analysis was performed by a colorimetric method with the anthrone reagent described by Osborne and Voogt [20]. Absorbance was monitored at $630 \mathrm{~nm}$ on an EZ210 UV/Vis Spectrometer (Perkin Elmer, Waltham, MA, USA) and an analytical curve of glucose (10-100 $\left.\mathrm{mg} \mathrm{mL}^{-1}\right)$ was used.

\section{Soluble sugars (SS)}

The content of SS was determined by High Performance Liquid Chromatography (HPLC) as reported by Cámara and coauthors [21] using an HPLC system equipped with PU II isocratic pumping system (Micron Analytical, SA, Spain), a Rheodyne valve, and a different refractometer R401 detector (Jasco, Madrid, Spain).

\section{Rheological properties}

The flow properties of the honey samples were evaluated at $30,40,50$, and $60^{\circ} \mathrm{C}$. A DVII-Pro viscometer (Brookfield Engineering Laboratories, USA) coupled to a T-184 thermostatic bath (Tecnal, Brazil) was used with the spindles SC4-18 (for sample RSb) and the SC4-34 (for the others). The apparent viscosity ( $\eta$ ) and shear stress were monitored in a 25-points curve. Data analysis was aided by Origin 8.6 software (OriginLab Corporation, USA). The Ostwald-de Waele (OW) and the Casson (CA) models were chosen to evaluate the flow curves [22,23]. Additionally, the effect of the temperature was assessed using an Arrhenius-type equation at $1.0 \mathrm{~s}^{-1}$ shear rate, as detailed elsewhere [18].

\section{Melissopalynological analysis}

Briefly, for the pollen sample preparation, $10 \mathrm{~mL}$ of honey was dissolved in $20 \mathrm{~mL}$ of distilled water, which was then centrifuged $(2,200 \mathrm{~g})$ for $15 \mathrm{~min}$. The sediment containing the pollen was used for the glass slides preparation $(76 \mathrm{~mm} \times 26 \mathrm{~mm})$. The observations were performed on a Zeiss Axio Observer D1 (Zeiss Vision $\mathrm{GmbH}$, Germany), equipped with AxioVision software (v. 4.8.2), with 1008x magnification. A total of 350 granules per image sample was assessed, sorting them into predominant pollen $(\geq 45 \%$ of the total of granules), accompanying pollen (15-44\%), rare pollen $(4-14 \%)$ and sporadic pollen $(\leq 3 \%)$. The $H$. dulcis pollen was identified using a JSM-6360 LV JEOL scanning electron microscopy (JEOL USA Inc., USA).

\section{Statistical analysis}

The data from triplicate assays were evaluated using the analysis of variance (ANOVA), followed by Duncan's test, using Statgraphics Plus 5.1 software (Statpoint Technologies, Inc, USA) at 5\% significance and presented as the mean \pm standard deviation, in addition to cluster linkage.

\section{RESULTS AND DISCUSSION}

\section{Chemical and physicochemical properties of Hovenia dulcis honey}

Figure 1a shows a graphical scheme for the melissopalynological analysis of Brazilian honey samples from the flowering of Hovenia dulcis Thunb $(\mathrm{HDH})$, while Figure 1b depicts the similarities between the samples according to its chemical and physicochemical properties. The chemical and physicochemical properties are shown in Table 1. 

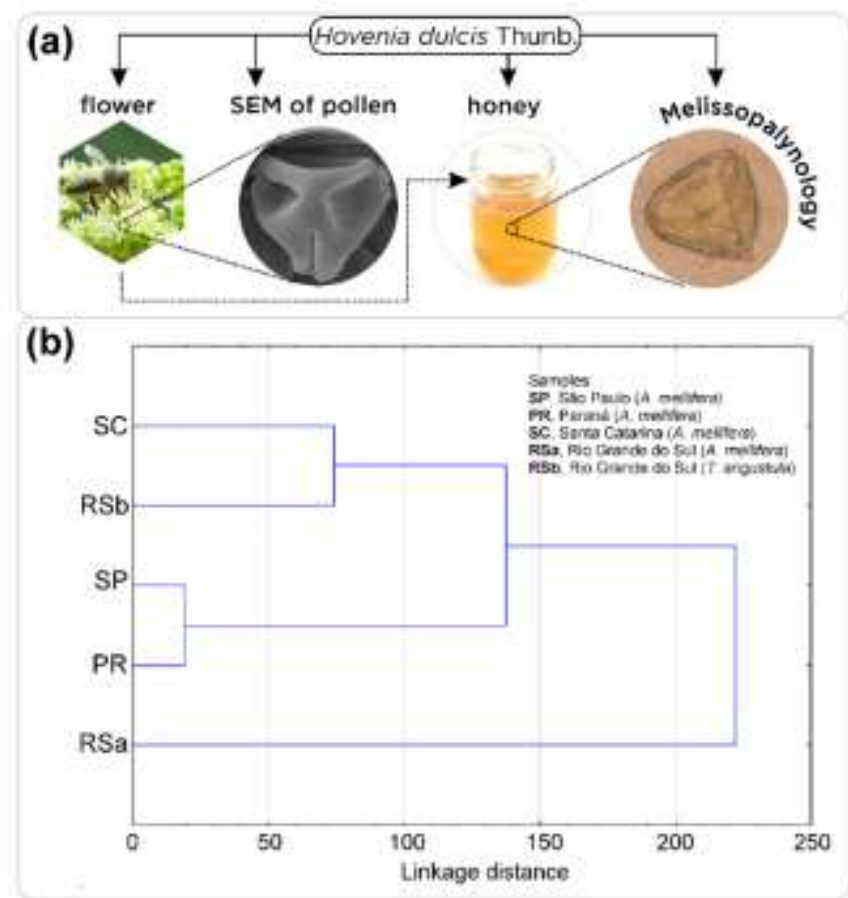

Figure 1. Melissopalynology of Hovenia dulcis honeys (a) and a dendrogram depicting the similarity between the samples (b).

The moisture content ranged from 17.00 to $19.73 \%$, with significant differences $(p<0.05)$ between the five samples. These results were below the maximum of $20 \%$ moisture limit for safety from fermentation, as required by Brazilian and international laws. Besides, these data indicate that the evaluated honey samples were in a proper degree of maturity. A water activity $\left(a_{w}\right)$ ranging from 0.569 to 0.695 was observed in the $\mathrm{HDH}$ samples. The sample with the highest $\mathrm{a}_{\mathrm{w}}$ also presented the highest moisture content and low levels of reducing sugars. This analysis is not a regulated parameter under the Brazilian law; however, aw values above 0.610 are critical and may contribute to the growth of osmotically tolerant yeasts, causing fermentation, and reducing its shelf life. Honey is commonly shelf-stable for a reasonable time when presenting low $a_{w}$ values, which allows a high osmotic environment and prevents microbial growth [13,24].

The free acidity (0.81-3.35 meq NaOH.100 g $\mathrm{g}^{-1}$ ) and $\mathrm{pH}$ values (3.59-4.64) confirmed that all $\mathrm{HDH}$ samples had an acidic character. Moreover, the $\mathrm{pH}$ values were within the standard limit (3.40-6.10), which ensures honey samples' freshness [25]. These two parameters are also critical antimicrobial factors; products with low $\mathrm{pH}$ and high acidity provide higher stability against microorganisms' growth. A variation between 5.02 to $8.73 \mathrm{~mL} . \mathrm{kg}^{-1}$ was verified for the content of formaldehyde. This index represents a global measure of amino compounds and allows the evaluation of the content of peptides, proteins, and amino acids, also crucial as adulterant indicator [2,24]. Proteins in samples ranged between $0.20 \mathrm{mg} .100 \mathrm{~g} \mathrm{~g}^{-1}$ (SP) to 0.57 $\mathrm{mg} .100 \mathrm{~g}^{-1}$ (PR). The origin of the honey and the type of pollen are variables that might cause differences in the protein content.

Ash content (AC) is usually mentioned as a quality standard for the botanical and geographical origin of honey. The AC of HDH was lower than $0.82 \mathrm{~g} .100 \mathrm{~g} \mathrm{~g}^{-1}$, and there were significant differences $(p<0.05)$ between samples. A. mellifera honeys PR, SC, and RSa, in addition to $T$. angustula honey RSb presented $A C$ in accordance with the Brazilian and international legislation that requires a maximum of $0.6 \mathrm{~g}^{1} 100 \mathrm{~g}^{-1}$ for monofloral honey [25,26]. In contrast, the AC of SP honey surpassed this limit. The AC is also associated with the pollen source adjacent to the apiary yard during honey production. The color of HDH samples was white to amber, with a few variations of this nuance (light amber and extra light amber). The honey samples $\mathrm{SC}$ and RSb presented minor values of ashes and clear coloring, corroborating with the literature [2,24].

The electrical conductivity (EC) values of $\mathrm{HDH}$ varied from 208.67 to $424.33 \mu \mathrm{S} . \mathrm{cm}^{-1}$. Brazilian legislation does not establish a reference for this feature, but international commissions have suggested a maximum limit of $800.0 \mu \mathrm{S} . \mathrm{cm}^{-1}$ [25]. There is a correlation between EC and ash content, $\mathrm{pH}$, acidity, minerals, and protein, and other compounds found in honey [24,27]. The hydroxymethylfurfural content ranged from 0.95 to $12.70 \mathrm{mg} \cdot \mathrm{kg}^{-1}$; therefore, the samples did not exceed the ceiling of $60.0 \mathrm{mg} \cdot \mathrm{kg}^{-1}$, as established by the 
Brazilian legislation [26], or the international standard [25] which limit is $80.0 \mathrm{mg} \cdot \mathrm{kg}^{-1}$, fixed for the honey of tropical regions.

Total reducing sugars (55.25 to $70.44 \mathrm{mg.} 100 \mathrm{~g}^{-1}$ ) and reducing sugars (55.59 to $72.39 \mathrm{mg}^{\circ} 100 \mathrm{~g} \mathrm{~g}^{-1}$ ) in $\mathrm{HDH}$ samples differed significantly. The fructose/glucose ratio $(F / G)$ in honey is not standardized by laws but is usually from order 1 to $2: 1$. This proportion is significant in technological terms, as it makes the flavor and graininess of the honey. Since fructose is sweeter and more soluble than glucose, the honey with a higher $\mathrm{F} / \mathrm{G}$ ratio is sweeter and remains liquid for more extended periods, also being an indicator of crystallization $[27,28]$. Other significant factors related to honey quality as the sum of fructose + glucose, as well as glucose/water (G/W) ratios, can be mentioned. In this scenario, the HDH samples presented a tendency to crystallize fast, since they showed a G/W ratio ranging from 2.24 (RSb) to 3.06 (RSa).

In a general way, the HDH samples can be grouped according to the similarities and differences between them, as shown in the dendrogram depicted in Figure 1b. The cluster analysis showed that the most different honey sample was the RSa, from the Rio Grande do Sul and produced by A. mellifera bees. On the other hand, PR and SP honeys present higher similarity with each other, while SC and RSb honeys were comparable. 
Table 1. Chemical and physicochemical properties of honey samples labeled as coming from the flowering of Hovenia dulcis produced by Apis mellifera (PR, RSa, SC, and $\mathrm{SP})$ and Tetragonisca angustula (RSb).

\begin{tabular}{|c|c|c|c|c|c|}
\hline Parameter & PR & RSa & RSb & SC & SP \\
\hline Water activity $\left(a_{w}\right)$ & $0.600 \pm 0.001^{b}$ & $0.596 \pm 0.001^{d}$ & $0.695 \pm 0.003^{a}$ & $0.569 \pm 0.001^{c}$ & $0.600 \pm 0.002^{b}$ \\
\hline $\mathrm{pH}$ & $4.61 \pm 0.01^{c}$ & $3.85 \pm 0.01^{d}$ & $4.74 \pm 0.02^{\mathrm{a}}$ & $4.64 \pm 0.01^{b}$ & $3.59 \pm 0.01^{\mathrm{e}}$ \\
\hline Total acidity (meq $\mathrm{NaOH} 100 \mathrm{~g}^{-1}$ ) & $2.69 \pm 0.07^{b}$ & $0.85 \pm 0.08^{c}$ & $3.35 \pm 0.32^{a}$ & $2.92 \pm 0.05^{b}$ & $0.81 \pm 0.02^{c}$ \\
\hline Formol index $\left(\mathrm{mL} \mathrm{kg}^{-1}\right)$ & $8.73 \pm 1.06^{\mathrm{a}}$ & $6.39 \pm 0.92^{b}$ & $5.38 \pm 0.33^{c}$ & $5.02 \pm 0.77^{c}$ & $6.68 \pm 1.14^{\mathrm{a}}$ \\
\hline Color (mm - Pfund scale) & $73.72 \pm 0.28^{b}$ & $34.73 \pm 0.24^{c}$ & $22.80 \pm 0.42^{\mathrm{e}}$ & $30.52 \pm 0.48^{d}$ & $85.83 \pm 0.22^{\mathrm{a}}$ \\
\hline Protein $\left(\mathrm{mg} 100 \mathrm{~g}^{-1}\right)$ & $0.57 \pm 0.06^{\mathrm{a}}$ & $0.45 \pm 0.01^{b}$ & $0.33 \pm 0.03^{c}$ & $0.48 \pm 0.05^{b}$ & $0.20 \pm 0.03^{d}$ \\
\hline 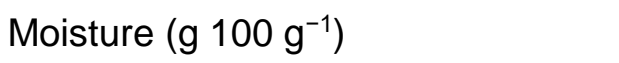 & $19.07 \pm 0.12^{b}$ & $17.00 \pm 0.01^{e}$ & $19.73 \pm 0.12^{a}$ & $17.73 \pm 0.12^{d}$ & $18.47 \pm 0.12^{\mathrm{c}}$ \\
\hline Ash $\left(g 100 g^{-1}\right)$ & $0.23 \pm 0.01^{b}$ & $0.15 \pm 0.01^{c}$ & $0.19 \pm 0.01^{b c}$ & $0.08 \pm 0.01^{d}$ & $0.82 \pm 0.06^{a}$ \\
\hline Hydroxymethylfurfural $\left(\mathrm{mg} \mathrm{kg}^{-1}\right)$ & $1.29 \pm 0.01^{d}$ & $0.95 \pm 0.03^{e}$ & $12.70 \pm 0.20^{\mathrm{a}}$ & $5.42 \pm 0.04^{c}$ & $6.75 \pm 0.04^{b}$ \\
\hline Electric conductivity $\left(\mu \mathrm{S} \mathrm{cm}^{-1}\right)$ & $419.33 \pm 1.15^{a}$ & $208.67 \pm 0.58^{d}$ & $370.33 \pm 9.87^{b}$ & $298.67 \pm 0.58^{c}$ & $424.33 \pm 0.58^{a}$ \\
\hline Total reducing sugars $\left(\mathrm{mg} 100 \mathrm{~g}^{-1}\right)$ & $70.44 \pm 7.10^{a}$ & $69.34 \pm 2.48^{a}$ & $55.25 \pm 3.83^{b}$ & $64.74 \pm 5.49^{a}$ & $62.43 \pm 3.04^{a b}$ \\
\hline - Fructose (mg $\left.100 \mathrm{~g}^{-1}\right)$ & $44.25 \pm 2.41^{a}$ & $43.35 \pm 1.43^{a}$ & $33.16 \pm 2.29^{b}$ & $44.51 \pm 5.25^{a}$ & $37.77 \pm 1.33^{\mathrm{b}}$ \\
\hline - Glucose (mg $\left.100 \mathrm{~g}^{-1}\right)$ & $26.19 \pm 5.51^{\mathrm{a}}$ & $25.98 \pm 1.39^{a}$ & $22.09 \pm 1.55^{\mathrm{ab}}$ & $20.23 \pm 2.43^{b}$ & $24.67 \pm 1.72^{\mathrm{ab}}$ \\
\hline Fructose/Glucose & $1.74 \pm 0.35^{\mathrm{a}}$ & $1.67 \pm 0.07^{a}$ & $1.50 \pm 0.01^{a}$ & $2.23 \pm 0.39^{b}$ & $1.53 \pm 0.06^{\mathrm{a}}$ \\
\hline Glucose/Water & $2.75 \pm 0.28^{\mathrm{ab}}$ & $3.06 \pm 0.08^{a}$ & $2.24 \pm 0.08^{b}$ & $2.28 \pm 0.14^{b}$ & $2.67 \pm 0.09^{a b}$ \\
\hline Total sugars $\left(\mathrm{mg} 100 \mathrm{~g}^{-1}\right)$ & $72.39 \pm 1.94^{a}$ & $55.59 \pm 1.63^{d}$ & $69.75 \pm 1.71^{b}$ & $65.54 \pm 1.28^{c}$ & $65.55 \pm 1.36^{c}$ \\
\hline
\end{tabular}

PR: Paraná; RSa and RSb: Rio Grande do Sul; SC: Santa Catarina; SP: São Paulo. Different letters mean significant differences in each column, according to Duncan's test $(p$ $<0.05)$. 


\section{Rheological behavior}

Figure 2 shows the main rheological properties of $\mathrm{HDH}$. The flow curves for the analyzed honeys at different temperatures are depicted in Figure 2a-e. Table 2 shows the calculated activation energy $\left(E_{\mathrm{a}}\right)$ and the apparent viscosity $(\eta)$ at different temperatures, in addition to the rheological parameters of the five honey samples fitted to the OW and CA models.
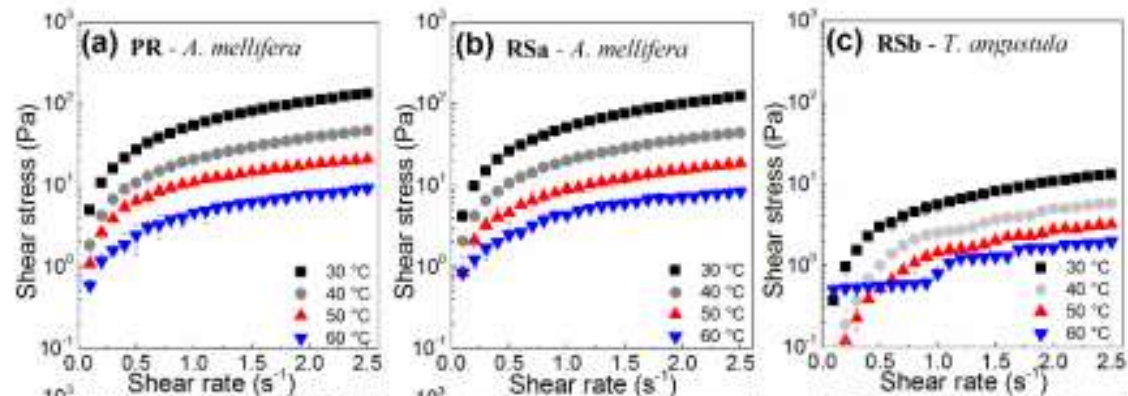

(d)
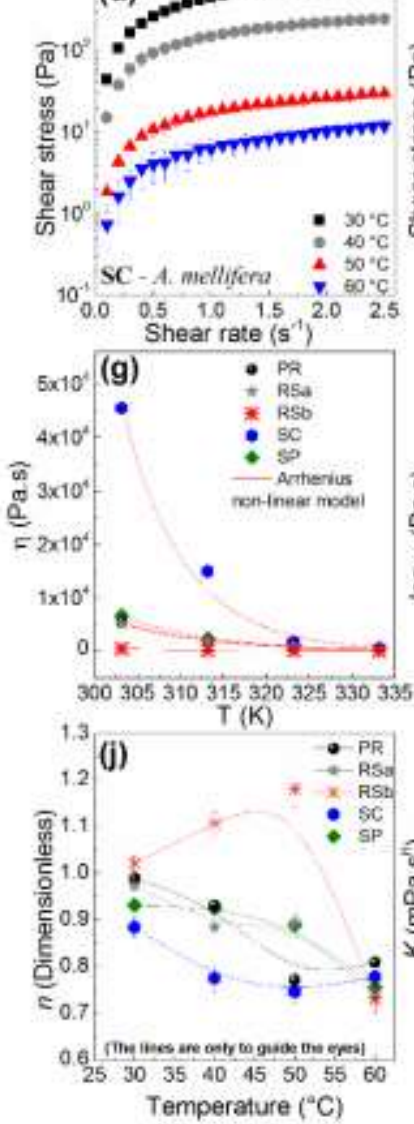
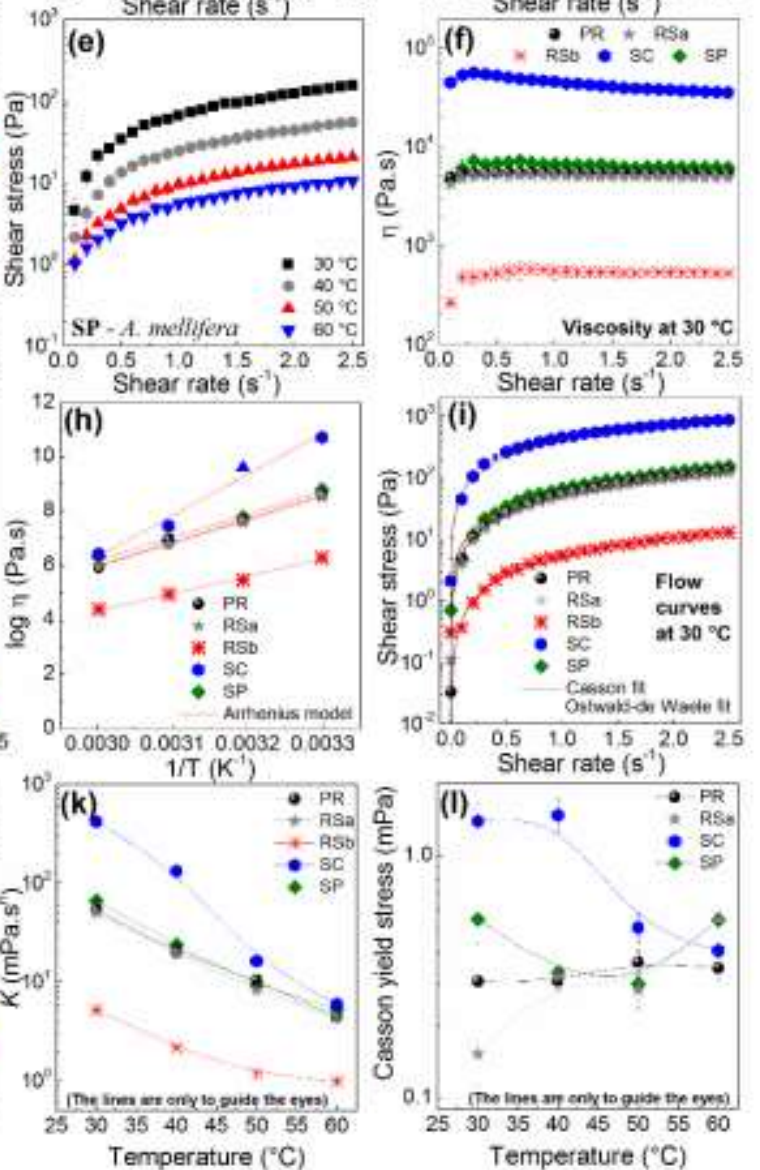
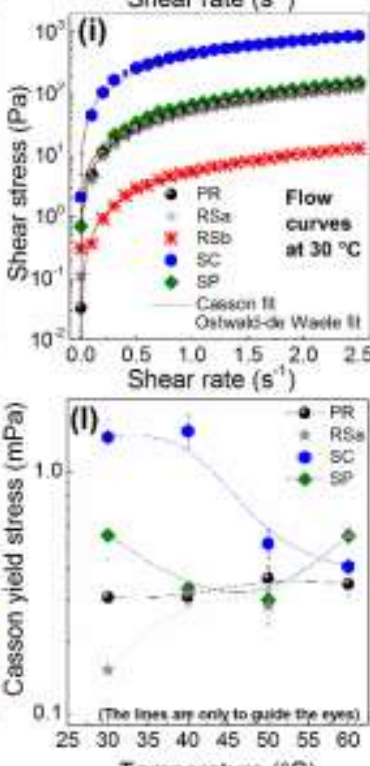

Figure 2. Flow (a-e) and viscosity (f) curves; non-linear (g) and linearized Arrhenius (h), CA, and OW (i) fittings, and the evolution of $n(\mathbf{j}), K(\mathbf{k})$ and $\sigma(\mathbf{I})$ parameters for $H$. dulcis honeys.

The viscosity of honey is dependent on factors such as moisture, the flowering of origin, the species of bees, the presence of crystals, among others [7,29]. By analyzing Table 2, the honey RSb produced by $T$. angustula bees presents lower $\eta$ than the other $\mathrm{HDH}$ samples at all temperatures studied, probably because of its higher moisture content $(\approx 19.8 \%)$ and small total reducing sugars content $(\approx 52.27 \%)$, as shown in Table 1. With increasing temperature, $A$. mellifera $\mathrm{HDH}$ exhibit similar $\eta$ values, but higher than that found for $T$. angustula honey. The HDH sample from Santa Catarina presented higher $\eta$ than others in all temperature ranges. As its moisture content was relatively high, the $\mathrm{HDH}$ RSb presented the lowest $\eta$, as expected. Although presenting the highest $\eta$, SC sample was the second, which showed less moisture content; therefore, other factors such as sugar content may also be influencing the viscosity of honey. From Figure $\mathbf{2 f}$, it is verified that at a constant temperature, the honey samples mostly show the same viscosity. 
One of the most critical parameters that influence viscosity is the temperature $(T)$, once the former is affected by the latter as the dissolved solids concentration. Figure $\mathbf{2 g}$ and Figure $\mathbf{2} \mathbf{h}$ represent the $\eta$ dependence of the $T$ and the fitting of the experimental data to the Arrhenius model, which fitted adequately $\left(R^{2} \geq 0.979\right)$ in all HDH samples. The sensitivity to the increase in $\mathrm{T}$ is represented by the activation energy $\left(E_{\mathrm{a}}\right)$ shown in Table 2. As expected, the $\eta$ decreases with increasing $\mathrm{T}$ (Figure 2 $\mathbf{g}$ ), and this occurs because when the sample is heated, the thermal energy between molecules rises, also increasing the intermolecular distance and consequently decreasing the $\eta[22,30]$. The SC sample showed the highest $E_{\mathrm{a}}\left(125.91 \mathrm{~kJ} \cdot \mathrm{mol}^{-1}\right)$, thus presenting more significant $\eta$ variation with changes in T. The SP, PR, and RSa samples achieved quite close values of $E_{\mathrm{a}}$, so the $T$ influences these three samples similarly. The honey with lower $\eta$ sensitivity to $T$ variations was the RSb. A linear relationship between log $\eta$ and $1 / T$ is observed for the samples SP, PR, RSa and RSb in all temperatures (Figure 2i); however, for sample SC there was a deviation of this behavior occurring at a $40^{\circ} \mathrm{C}$, i.e., the values of the $\eta$ were lower than the expected following the trend observed at the other temperatures.

Table 2. Activation energy $\left(E_{\mathrm{a}}\right)$, and apparent viscosity $(\eta)$ at different temperatures, and rheological parameters fitted to the Ostwald-de Waele and Casson models for honey samples from Hovenia dulcis analyzed at $30^{\circ} \mathrm{C}$.

\begin{tabular}{|c|c|c|c|c|c|}
\hline \multirow{2}{*}{ Sample } & \multirow{2}{*}{$E_{\mathrm{a}}\left(\mathrm{kJ} \cdot \mathrm{mol}^{-1}\right)$} & \multicolumn{4}{|c|}{$\eta$ at $1.0 \mathrm{~s}^{-1}(\mathrm{mPa} . \mathrm{s})$} \\
\hline & & $30^{\circ} \mathrm{C}$ & $40^{\circ} \mathrm{C}$ & $50^{\circ} \mathrm{C}$ & $60^{\circ} \mathrm{C}$ \\
\hline PR & 72.33 & $5442.04 \pm 76.97^{b}$ & $2071.56 \pm 128.28^{b}$ & $1074.97 \pm 71.26^{b}$ & $382.37 \pm 85.48^{b}$ \\
\hline $\mathrm{RSa}$ & 71.26 & $5078.12 \pm 107.99 b$ & $1993.17 \pm 102.63^{b}$ & $895.81 \pm 135.81^{b}$ & $391.92 \pm 53.92^{b}$ \\
\hline $\mathrm{RSb}$ & 52.65 & $547.68 \pm 91.78^{c}$ & $240.67 \pm 24.83^{c}$ & $142.70 \pm 0.15^{c}$ & $80.98 \pm 22.91^{c}$ \\
\hline SC & 125.91 & $45503.89 \pm 3528.56^{a}$ & $\begin{array}{c}15027.19 \pm \\
1640.14^{\mathrm{a}}\end{array}$ & $\begin{array}{c}1758.02 \pm \\
277.18^{\mathrm{a}}\end{array}$ & $627.07 \pm 185.78^{a}$ \\
\hline SP & 70.70 & $6686.57 \pm 265.70^{b}$ & $2428.28 \pm 182.87^{b}$ & $962.99 \pm 119.16^{b}$ & $554.28 \pm 95.01^{\mathrm{ab}}$ \\
\hline Sample & Model & $K\left(\mathrm{mPa} . \mathrm{s}^{n}\right)$ & $n$ & $R^{2}$ & $x^{2}$ \\
\hline PR & & $53.76 \pm 0.12^{c}$ & $0.99 \pm 0.00^{b}$ & 0.9996 & 0.36 \\
\hline $\mathrm{RSa}$ & $\frac{1}{0} \frac{0}{0}$ & $50.45 \pm 0.17^{d}$ & $0.97 \pm 0.01^{c}$ & 0.9995 & 0.54 \\
\hline $\mathrm{RSb}$ & $\sum_{3}^{\pi} \sum^{\pi}$ & $5.22 \pm 0.07 e$ & $1.02 \pm 0.02^{a}$ & 0.9936 & 1.85 \\
\hline SC & 0 & $421.98 \pm 6.37^{a}$ & $0.88 \pm 0.02^{\mathrm{e}}$ & 0.9853 & 1.18 \\
\hline $\mathrm{SP}$ & & $65.82 \pm 0.50^{\mathrm{b}}$ & $0.93 \pm 0.01^{d}$ & 0.9950 & 0.40 \\
\hline & & $\sigma_{0}(\mathrm{mPa})$ & $\overline{K_{\mathrm{C}}}$ & $R^{2}$ & $x^{2}$ \\
\hline PR & & $0.04 \pm 0.02^{\mathrm{d}}$ & $7.28 \pm 0.02^{c}$ & 0.9997 & 0.44 \\
\hline $\mathrm{RSa}$ & c & $0.15 \pm 0.04^{c}$ & $6.93 \pm 0.03^{d}$ & 0.9997 & 0.80 \\
\hline $\mathrm{RSb}$ & W & $0.08 \pm 0.04^{c, d}$ & $2.36 \pm 0.04^{\mathrm{e}}$ & 0.9868 & 3.81 \\
\hline SC & 0 & $1.34 \pm 0.35^{a}$ & $18.96 \pm 0.37^{a}$ & 0.9821 & 1.72 \\
\hline $\mathrm{SP}$ & & $0.46 \pm 0.12^{b}$ & $7.62 \pm 0.11^{b}$ & 0.9964 & 0.56 \\
\hline
\end{tabular}

$K=$ consistency coefficient; $n=$ flow behavior index (dimensionless); $\sigma_{0}=$ Casson yield stress; $K_{\mathrm{C}}=$ Casson plastic viscosity; $R^{2}=$ coefficient of determination; $X^{2}=$ chi-square .

It is important to emphasize that the application of models always represents an excellent way to better understand the nature of foods [29-31]. Thus, the experimental data were analyzed by the CA and OW models (Table 2 and Figure 2i). From those items is verified that the experimental data showed a good fit for the OW model $\left(R^{2}>0.99 ; X^{2}<3.0\right)$. As shown in Table 2 and Figure $2 \mathbf{j}$, the samples SP, SC, and RSa presented almost Newtonian behavior $(n \approx 1)$ at $30^{\circ} \mathrm{C}$, while PR and RSb showed $n=1$. However, at 40 and $50{ }^{\circ} \mathrm{C}$, the sample RSb presented an unusual behavior and became shear-thickening $(n>1)$, and then achieved a non-Newtonian behavior $(n<1)$ at $60^{\circ} \mathrm{C}$, the temperature in which all the others already were presented as shear-thinning fluids, revealing a pseudoplastic character. Furthermore, except for honey RSb, an increase in $\mathrm{T}$ tends to cause a decrease in the $n$ parameter. Figure $\mathbf{2 k}$ reveals that $\mathrm{SC}$ had the most consistent flow (more viscous) since the $K$ values were the highest (422.0-6.0 mPa. $\left.\mathrm{s}^{n}\right)$ in all the temperature range tested. In contrast, $\mathrm{RSb}$ was the less consistent $\left(K=5.2-1.0 \mathrm{mPa} \cdot \mathrm{s}^{\mathrm{n}}\right)$. Considering that $K$ is correlated to the $\eta$, these data agree with the values presented in Table 2 for the $\eta$.

A proper fitting by using the CA model $\left(R^{2}=0.98-0.99 ; X^{2}=0.56-3.81\right)$ and positive values for CA yield stress $\left(\sigma_{0}\right)$ ranging from 0.044 to $1.345 \mathrm{mPa}$ was also observed (Table 2). The T had little influence on $\sigma_{0}$ (Figure 2I) since the samples presented small variations in its values, except for honey SC, which showed the highest $\sigma_{0}$ with a decrease during heating. The adjust for RSb sample to the CA model was not possible 
at the temperatures of $40-60{ }^{\circ} \mathrm{C}$. As also predicted by the OW model, Table 3 shows that the SC sample presented the highest CA consistency coefficient $\left(K_{\mathrm{C}}\right)$, while RSb showed the smallest $K_{\mathrm{C}}$ value.

\section{Melissopalynological analysis}

The melissopalynological analysis could identify and quantify the $H$. dulcis pollen in the samples (Figure 3a-d). The analysis revealed a high qualitative diversity of pollen types. For SP and RSb, the amount of $H$. dulcis pollen was lower than $45 \%(29.14 \%$ and $33.14 \%$, respectively). As there was no identification of the other botanical species, these honey samples are likely to be referred to as polifloral-type, but cannot be labeled as honey from $H$. dulcis flowering. Another pollen type may also be predominant in these samples if its contribution accounts for more than $45 \%$, which was not possible to verify. The $H$. dulcis pollen in the honey from Santa Catarina (SC) accounted for $63.14 \%$, while the sample from Paraná State (PR) presented $57.14 \%$, and honey RSa showed $69.07 \%$ of pollen from $H$. dulcis species (standard deviations $<0.5$ ).
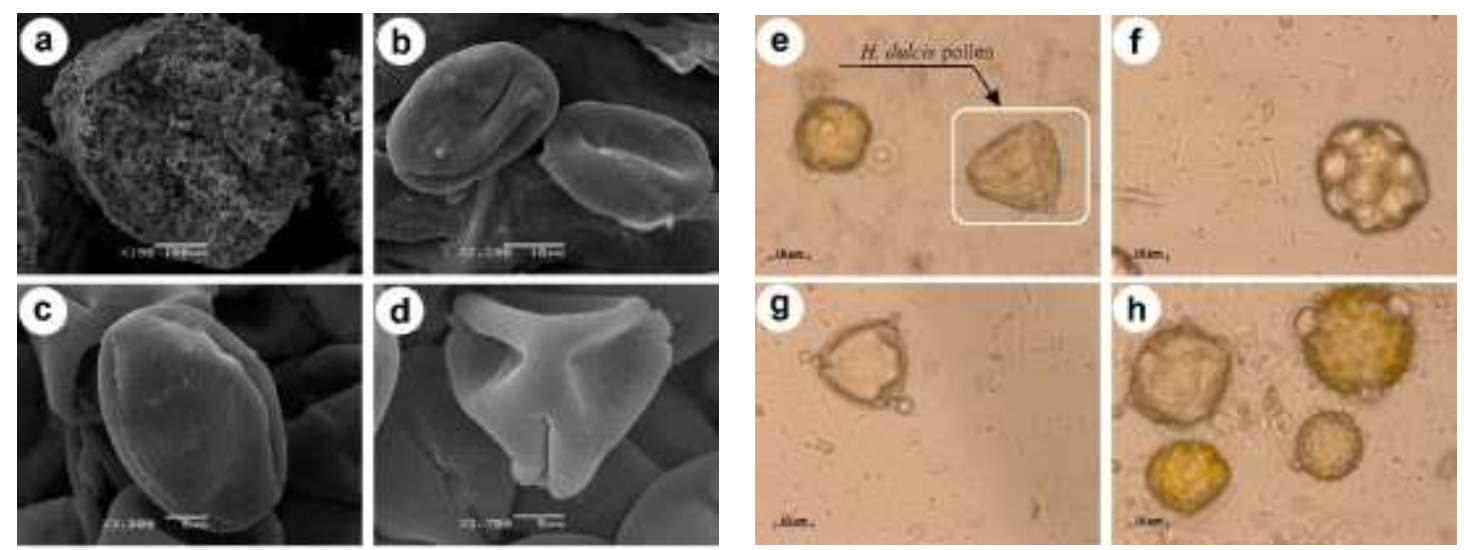

Figure 3. SEM (a-d), and optical micrographs of $H$. dulcis pollen (e) compared to non-identified pollens from the honey samples $(\mathbf{f}, \mathbf{g}, \mathbf{h})$.

Variations of pollen types (Figure 8e-h) and their frequencies in the sample may be related with changes in the production of pollen and nectar by the plant on the basis of interactions with climatic factors, in addition to the differences in collection strategies and floral preferences specific to each bee species [27]. In some situations, the bees can get other sources of supply or use different collection schedules to avoid competition with other species. Regarding the classification according to the occurrence of grains, only three analyzed samples (PR, SC, and RSa) were correctly labeled once they presented $>45 \%$ of $\mathrm{H}$. dulcis dominant pollen $[9,27]$.

\section{CONCLUSIONS}

The evaluated $H$. dulcis honey samples showed quality parameters following both Brazilian and international legislation. The rheological properties of $\mathrm{HDH}$ were adequately described by the Ostwald-de Waele and Casson models, revealing their pseudoplastic character. The melissopalynology confirmed the predominant pollen in the honey; however, two samples did not show $\mathrm{H}$. dulcis as the most frequent pollen $(<45 \%)$, revealing cases of mislabeling. Thus, the results reported herein highlight the importance of constant evaluation of honey and represent an alert for the Brazilian honey's market in the regard that high-addedvalue honey can easily be a target of fraud. It can help both government regulatory authorities and producers in the quality control routines avoiding fraud and mislabeling, which may be unintentional but represents a risk for consumers.

Funding: This research was funded by Coordenação de Aperfeiçoamento de Pessoal de Nível Superior CAPES/Brazil, grant number BEX 3480/13-5, and the frame of ALIMNOVA UCM group (951505) in Spain.

Acknowledgments: We thank CAPES for the postdoctoral scholarship granted to G. L. Teixeira (grant numbers 1795263 and 88882.316463/2019-01).

Conflicts of Interest: The authors declare no conflict of interest.

\section{REFERENCES}

1. Hempattarasuwan P, Settachaimongkon S, Duangmal K. Impact of botanical source and processing conditions on physicochemical properties and antioxidant activity of honey in the northern part of Thailand. Int J Food Sci Technol. 
2019;54(12):3185-95.

2. Ávila S, Beux MR, Ribani RH, Zambiazi RC. Stingless bee honey: Quality parameters, bioactive compounds, health-promotion properties and modification detection strategies. Trends Food Sci Technol. 2018;81:37-50.

3. Se KW, Wahab RA, Syed Yaacob SN, Ghoshal SK. Detection techniques for adulterants in honey: Challenges and recent trends. J Food Compos Anal. 2019;80:16-32.

4. Soares S, Amaral JS, Oliveira MBPP, Mafra I. A Comprehensive Review on the Main Honey Authentication Issues: Production and Origin. Compr Rev Food Sci Food Saf. 2017;16(5):1072-100.

5. Naila A, Flint SH, Sulaiman AZ, Ajit A, Weeds Z. Classical and novel approaches to the analysis of honey and detection of adulterants. Food Control. 2018;90:152-65.

6. Ugur HG, Sıralı R, Tekgul AT, Efe B. Investigation of mad honey use as an alternative treatment in patients admitted to the pulmonary clinic: Ordu, Turkey example. Brazilian Arch Biol Technol. 2019;62.

7. Oroian M, Ropciuc S, Paduret S. Honey authentication using rheological and physicochemical properties. J Food Sci Technol. 2018;55(12):4711-8.

8. EIMasry G, Morsy N, Al-Rejaie S, Ayed C, Linforth R, Fisk I. Real-time quality authentication of honey using atmospheric pressure chemical ionisation mass spectrometry (APCI-MS). Int J Food Sci Technol. 2019;1-15.

9. Costa ACV da, Sousa JMB, da Silva MAAP, Garruti D dos S, Madruga MS. Sensory and volatile profiles of monofloral honeys produced by native stingless bees of the Brazilian semiarid region. Food Res Int. 2018;105:11020.

10. Kayani S, Hussain M, Ahmad M, Zafar M, Sultana S, Butt MA, Ali S, Shah GM, Mir S. Scanning Electron Microscopy (SEM) and Light Microscopy (LM)-based Palyno-morphological views of Solanaceae in Western Himalaya. Microsc Res Tech. 2019;82(2):63-74.

11. Adgaba N, Al-Ghamdi AA, Getachew A, Tadesse Y, Belay A, Ansari MJ, Radloff SE, Sharma D. Characterization of honeys by their botanical and geographical origins based on physico-chemical properties and chemo-metrics analysis. J Food Meas Charact. 2017;11(3):1106-17.

12. Castiglioni S, Stefano M, Pisani M, Carloni P. Geographical characterisation of multifloral honeys from the Marche region (Italy) according to their antioxidant activity and colour using a chemometric approach. Int J Food Sci Technol. 2018;53(3):571-81.

13. Mădaş MN, Mărghitaş LA, Dezmirean DS, Bobiş $O$, Abbas $O$, Danthine $S$, Francis F, Haubruge E, Nguyen BK. Labeling Regulations and Quality Control of Honey Origin: A Review. Food Rev Int. 2019;00(00):1-26.

14. Haidamus SL, Lorenzon MCA, Koshiyama AS, Tassinari W de S. Floral Diversity in Different Types of Honey. Brazilian Arch Biol Technol. 2019;62:e19180241.

15. Oroian M, Ropciuc S, Buculei A. Romanian honey authentication based on physico-chemical parameters and chemometrics. J Food Meas Charact. 2017;11(2):719-25.

16. Witczak M, Juszczak L, Gałkowska D. Non-Newtonian behaviour of heather honey. J Food Eng. 2011;104(4):5327.

17. Sakdatorn V, Thavarungkul N, Srisukhumbowornchai N, Intipunya P. Improvement of rheological and physicochemical properties of longan honey by non-thermal magnetic technique. Int $\mathrm{J}$ Food Sci Technol. 2018;53(7):1717-25.

18. Maieves HA, Bosmuler Züge LC, Scheer ADP, Ribani RH, Morales P, Sánchez-Mata MC. Physical properties and rheological behavior of pseudofruits of Hovenia dulcis Thunb. in different maturity stages. J Texture Stud. 2017;48(1):31-8.

19. AOAC. Official Methods of Analysis. 18th ed. Association of Official Analytical Chemists. Gaithersburg: AOAC International; 2007.

20. Osborne DR, Voogt P. Análisis de los nutrientes de los alimentos. Zaragoza: Acribia; 1986.

21. Cámara MM, Díez C, Torija ME. Free sugars determination by HPLC in pineapple products. Z Lebensm Unters Forsch. 1996;202(3):233-7.

22. Dianat M, Taghizadeh M, Shahidi F, Razavi SMA. The flow properties of honey-malt spread. Food Sci Technol Int. 2017;23(5):415-25.

23. Teixeira GL, Ribani RH. Rheological Properties and Microstructure of Canola-Based Emulsions Stabilized with Polyoxyethylene Sorbitan Surfactants. Res Dev Mater Sci. 2018;6(1):542-6.

24. Sereia MJ, Março PH, Perdoncini MRG, Parpinelli RS, de Lima EG, Anjo FA. Techniques for the Evaluation of Physicochemical Quality and Bioactive Compounds in Honey. In: Honey Analysis. InTech; 2017. p. 193-214.

25. Codex Alimentarius Commission. Codex Alimentarius Commission Standards. Codex Stan 12-1981. 2001;1-8.

26. Brazil. Technical regulation of identity and quality of honey (in Portuguese) [Internet]. Normative Instruction n. 11, from the Brazilian Ministry of Agriculture Livestock and Food Supply. Brasília; 2000 [cited 2019 Dec 10]. Available from: http://extranet.agricultura.gov.br/sislegis-consulta/servlet/VisualizarAnexo?id=1690

27. El Sohaimy SA, Masry SHD, Shehata MG. Physicochemical characteristics of honey from different origins. Ann Agric Sci. 2015;60(2):279-87.

28. Buba F, Gidado A, Shugaba A. Analysis of Biochemical Composition of Honey Samples from North-East Nigeria. Biochem Anal Biochem. 2012;2(3):1-7. 
29. dos Santos FKG, Filho AND, Leite RHL, Aroucha EMM, Santos AG, Oliveira TA. Rheological and some physicochemical characteristics of selected floral honeys from plants of caatinga. An Acad Bras Cienc. 2014;86(2):981-94.

30. Rao MA. Rheology of Fluid, Semisolid, and Solid Foods. Boston, MA: Springer US; 2014. 461 p. (Food Engineering Series; vol. 19).

31. Izidoro DR, Scheer A de P, Sierakowsk M-R. Rheological properties of emulsions stabilized by green banana (Musa cavendishii) pulp fitted by power law model. Brazilian Arch Biol Technol. 2009;52(6):1541-53.

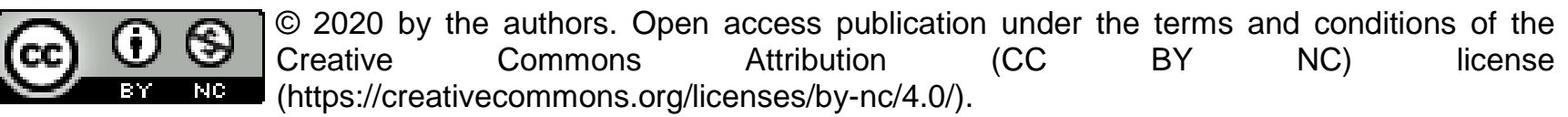

